\section{СПИСОК ВИКОРИСТАНОЇ ЛІТЕРАТУРИ}

1. Бакай С. Ю. Музикотерапія та вокалотерапія у сучасному педагогічному процесі / С. Ю. Бакай, О. А. Мкртічян // Науковий часопис НПУ імені М. П. Драгоманова. - 2011. - Вип. 14. - С. 13-16. (Серія 16 «Творча особистість учителя: проблеми теорії і практики»). URL: http://nbuv.gov.ua/ UJRN/Nchnpu_016_2011_14_5 (дата звернення: 15.08.2019).

2. Волженцева I. В. Оптимізація психічних станів студентів у навчальній діяльності засобами музичного впливу : автореф. дис. на здобуття наук. ступеня канд. псих. наук : 19.00.07 «Педагогічна і вікова психологія» / І. В. Волженцева. - Київ, 2006. - 20 с.

3. Драганчук В. М. Музика як фактор психокорегування: історичний, теоретичний і практичний аспекти : автореф. дис. на здобуття наук. ступеня канд. мистецтвознавства : 17.00.03 «Музичне мистецтво»/ В. М. Драганчук. - Київ, 2003. - 20 с.

4. Квітка Н. Методичний посібник із музикотерапії для дітей дошкільного віку зі складними порушеннями психофізичного розвитку / Н. Квітка. - К. : 2013. -82 c.

5. Кузьмінська Л. Зміст та цілі музикотерапії в соціально-педагогічній роботі 3 дітьми-інвалідами / Л. Кузьмінська // Освіта регіону. Політологія. Психологія. Комунікації: український науковий журнал. 2011. - № 4. URL: http://www.social-science.com.ua/ article/711 (дата звернення: 18.08.2019).

УДК 78.071:780.616.432(477)

DOI: 10.37026/2520-6427-2019-100-4-170-173
6. Литвинчук Л. М. Особливості корекційного впливу музикотерапії / Л. М. Литвинчук // Проблеми сучасної психології : збірник наукових праць Кам'янець-Подільського національного університету ім. І. Огієнка. - 2012. - Вип. 15. - С. 322-330.

7. Малашевська I. А. Теорія і практика навчання музики дітей дошкільного та молодшого шкільного віку з використанням музикотерапії : автореф. дис. на здобуття наук. ступеня д-ра пед. наук : 13.00.02 «Теорія та методика музичного навчання». - Київ, 2017. - 36 с.

8. Терентьєва Н. О. Терапевтичний вплив музики: історико-методичний аспект / Н. О. Терентьєва, М. В. Гладков // Педагогічні науки : збірник наукових праць Херсонського державного університету. 2017. - Вип. 79. - Т. 2. - С. 46-51.

9. Тітова А. В. Можливості застосування музикотерапії у вищій школі та її вплив на успішність майбутніх лікарів / А. В. Тітова // Вісник ВДНЗУ «Українська медична стоматологічна академія». - 2015. Вип. 2 (50). - Т. 15. - С. 224-227.

10. Товтин Н. І. Історико-теоретичні засади музикотерапії / Н. І. Товтин // Україна - Цивілізація. Том 6. Консолідація української держави, нації та церкви: зовнішні та внутрішні чинники. - Ужгород : Видавничий відділ КаУ, 2017. - С. 289-298.

11. Щедролосєва К. О. Музикотерапія та ії лікувально-педагогічні можливості / К. О. Щедролосєва. URL: www.ksdu.ks.ua/FileDownload.ashx (дата звернення: 20.08.2019).

Дата надходження до редакиіï: 21.08.2019 р.

Жанна ДАЮК,

кандидат педагогічних наук, доцент кафедри естрадної музики Інституту мистеитв

Рівненського держсавного гуманітарного університету

Анастасія МОСІЙЧУК, студентка магістратури кафедри естрадної музики Інституту мистеитв

Рівненського держсвного гуманітарного університету

\title{
ДИТЯЧА ФОРТЕПІАННА МУЗИКА НА ТЕРЕНАХ УКРАЇНИ
}

У статті висвітлено питання про зародження дитячої фортепіанної музики та ї̈ представників на теренах України. Представлено періодизацію та аналіз творчої спадщини окремих композиторів. 3'ясовано, якою саме музикою виховували та прищеплювали в дітей любов до народної культури. Систематизовано та узагальнено відомості щзодо створених збірок, окремих ииклів фортепіанних п'єс для дітей, написаних відомими українськими композиторами.

Ключові слова: дитяча фортепіанна музика, цикли, п'єси, фортепіанні збірки, украӥнські композитори.
В статье освешены вопросы о зарождении детской фортепианной музыки и ее представителей на территории Украины. Представлена периодизачия $u$ анализ творческого наследия отдельных композиторов. Выяснено, какой именно музыкой воспитьвали и прививали у детей любовь к народной культуре. Систематизированы и обобщены сведения о созданных сборниках, отдельных ичиклах фортепианных пьес для детей, написанных известными украинскими композиторами.

Ключевые слова: детская фортепианная музы-

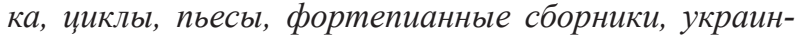
ские композиторы. 
The article covers the issue of the birth of children's piano music by its representatives. Periodization and analysis of the creative heritage of individual composers were made, changes in the artistic content were investigated, and what they caused in children's piano music. Finding out what kind of music brought up and instilled a love of folk culture and why it was so important. Systematized and summarized information about the created collections, individual cycles of piano pieces for children of Ukrainian composers and contemporary artists. The influence of music on children and peculiarities of child psychology are investigated.

The independence and humanity of the musical images of the piano works of Ukrainian contemporary authors is explained by the intonational unity with the folk music, which is the embodiment of the national spirit, psychological essence, unique personality of the national character. Even in the lightest pieces intended for the youngest listeners, you can see interesting examples of artistic processing of folk tunes. Handling playful songs and dance music introduces children to such folk traits as cheerfulness, humor, ingenuity. The interest in folk song will be enhanced by revealing the richness of its content, since children are simply obliged to know their native music and teachers need to actively instill a love for it.

In the 19th - 20th centuries, the first contribution to the birth of children's piano music was made by the following composers: M. Lysenko, J. Stepovy, S. Ludkevich, L. Revutsky. V. Kosenko continued to develop this direction. F. Barvinsky, N. Nizhankivsky, L. Dychko, M. Skoryk and L. Kolodub. 21st Century Children's Heritage is filled with the colorful and creative work of many young composers. The national-educational potential of these works, the development of basic performing skills, the formation of independence of musical thinking on the material of folk song is an important basis for their replenishment of the modern pedagogical repertoire of Ukraine.

Key words: children's piano music, cycles, plays, piano pieces, Ukrainian composers.

Постановка проблеми. В українському музичному мистецтві досі немає досить глибокого аналітичного дослідження творчого спадку українських композиторів у галузі дитячої фортепіанної музики. Зокрема, не з'ясовані основні риси художнього змісту такої музики, ії типізація, не визначені ознаки національної музичної мови та характерність образного змісту тощо.

Актуальність проблематики становить значна кількість невирішених проблем, що потребують уточнення періодизації дитячої фортепіанної музики України, без якої неможливо усвідомити шляхи ії розвитку та виявити орієнтири на різних етапах; також недослідженим залишається внесок видатних українських композиторів у становлення дитячої музики як засобу формування особистості. Зважаючи на це, мета статті - дослідити розвиток дитячої фортепіанної музики у творчості видатних українських композиторів.

Аналіз наукових досліджень та публікацій. У творчій діяльності українських композиторів важливе місце посідають інструментальні твори для дітей, серед яких значну частину становить дитяча фортепіанна музика. Означений напрям розглядали М. Лисенко, М. Скорик, В. Косенко, Ж. Колодуб, Л. Грабовський, І. Щербакова, М. Степаненко, Г. Сасько, О. Костіна, В. Сильвестров, В. Бібік та Г. Гаврилець, праці яких стали не лише продовженням успіху
К. Дебюссі, Р. Шумана, С. Прокоф’єва та П. Чайковського, а й цінним самостійним проявом у музичному мистецтві.

Дитячі фортепіанні твори українських композиторів здебільшого використовувалися як дидактичний матеріал, що сприяв розвитку творчих здібностей учнів, які навчалися в дитячих музичних школах. Останнім часом зріс інтерес до проблем сприйняття музики дітьми 3 погляду психології (В. Драганчук) та дослідження принципу програмності в дитячій інструментальній музиці України (О. Фрайт).

Виклад основного матеріалу. У творчості значної кількості вітчизняних композиторів можемо знайти елементи музики для дітей, що свідчить про їх неабияку музично-педагогічну діяльність у різноманітних видах та жанрах музики.

Особливо цінною є творча праця піаністів-педагогів у написанні музики для дітей, оскільки саме вони якнайкраще змогли поєднати композиторський задум iз фортепіанною педагогікою та здобути вагомі досягнення у фортепіанному педагогічному репертуарі.

Друга половина XIX століття відзначалася розквітом музичної освіти, зокрема й фортепіанного мистецтва. Важливий внесок у професійне становлення та розвиток фортепіанної музики для дітей зробив композитор М. Лисенко (1842 - 1912 рр.), написавши твори для дітей: «Коза-дереза» (1880р.), «Пан Коцький» (1891р.), «Зима і Весна» (1892р.). У його дитячих операх втілилися естетичні погляди композитора щодо виховання дітей на основі народного мистецтва. Традиції М. Лисенка продовжили такі композитори, як В. Сокальський, М. Калачевський, Я. Степовий, С. Людкевич, Л. Ревуцький та ін.

Першими українськими композиторами, які розпочали писати дитячу фортепіанну музику, були М. Вілінський, Ф. Надененко, В. Барвінський та Б. Яновський. Так, у 1923 р. М. Вілінський створює «Дитячий альбом», у 1926 р. видає збірку п’єс «Бублики» Б. Яновський, а у 1925-1927 рр. низку дитячих творів випускає Ф. Надененко.

О. Олійник, досліджуючи історію зародження та розвитку дитячої музики, пише, що у 20-30-х роках XX століття створюються перші дитячі музичні школи та виникає проблема 3 дитячим фортепіанним репертуаром. Задля того, щоб мати нотний матеріал для навчання, викладачі перекладали класичні твори Л. Бетховена, Ф. Шуберта, И. Брамса, М. Глінки та ін. Доробки українських композиторів $\epsilon$ кращими зразками музики для дітей ХІХ століття. У 1914 р. Я. Степовий створив цикл «Збірник українських творів для фортепіано», що вміщував обробки народної музики конкретно для дитячої фортепіанної музики. Цього ж року він пише цикл «Перші кроки несміливого музиканта», що характеризується романтичними настроями, розмаїттям та програмністю творів [7, с. 5].

Створював цикли для найменших виконавців і композитор Л. Ревуцький («Три дитячі п’єси» (1929 р.)), в яких використовував елементи народних мелодій для того, щоб музика була близькою до повсякденного життя і більш зрозумілою для сприйняття дітьми. У 1936 р. В. Косенко пише цикл «24 дитячі п'єси», побудований за тональностями квартоквінтового кола. Автор звернувся до танців епохи імпресіонізму, запозичивши ідею у Р. Шумана та П. Чайковського, яким була характерна програмність, що відображалася в образах природи («На узліссі», «За метеликом», «Ранком у садочку», «Дощик»), 
Означений цикл був досить оригінальним завдяки оновленому яскравому звучанню із застосуванням підголосків та свіжих інтонацій.

Засновниками української дитячої фортепіанної музики є В. Косенко (Східна Україна) та В. Барвінський (Західна Україна). Останній надзвичайно захопився створенням дитячого фортепіанного репертуару, який набув високого професійного рівня не лише в педагогіці, а й жанрі дитячої фортепіанної музики. Усвідомлюючи нестачу вітчизняного педагогічного репертуару, особливо 3 рисами національної ментальності, В. Барвінський створив чотири збірки, написані переважно на основі українського фольклору і спрямовані на дітей різного віку: «Шість мініатюр на українські народні теми» (1925 р.), «Українські народні пісні для фортепіано» (для дітей середнього віку (1929 р.)), а також 2 цикли, що вийшли друком у 1935 р.: «Колядки та щедрівки» (для старших учнів) та «Наше сонечко грає на фортепіано» (для маленьких початківців). Цикли були створені на основі народних пісень. Таким чином, В. Барвінський ставив собі за мету прищеплювати любов і розуміння народної музики із якомога молодшого віку $[1$, с. 8$]$.

Проблема нестачі репертуару для дітей дуже турбувала В. Барвінського, самостійно він не міг із цим впоратися, тому звернувся до інших українських композиторів із проханням писати фортепіанну музику для дітей. Першим відгукнувся Н. Нижанківський, створивши збірку дитячих п’єс «Фортепіанні твори для молоді» (1935р.). Композитор поєднав кращі досягнення української та європейської музичної культури, як наслідок - з'являється новий тип музики, в якій фольклорні інтонації переплітаються 3 класичною основою. Гармонія наповнена багатьма хроматизмами та альтерованими зворотами. Автор не цитує, а перетворює ритмо-структурні, ладо-гармонічні та інтонаційні звороти народної музики [2, с. 40].

Композитори першої половини ХХ століття брали за основу український фольклор та урізноманітнювали його в усіх можливих жанрових течіях, адже прагнули, щоб молоде покоління вчилося на основі рідних їм традицій, пісень та обрядів, а в майбутньому прищеплювало любов до музики своїм дітям.

У 60-х рр. своєю творчою діяльністю прославилися молоді композитори-авангардисти: М. Скорик, Л. Грабовський, В. Сильвестрова, Є. Бібік, Л. Дичко, Є. Станкович, які захоплюються в дитячих творах прийомами сонористики, алеоторики, незвичними засобами музичної та стилістичної виразності. Також у цей час спостерігається формування нових різновидів пісенно-танцювальних сюїт, циклів мініатюр, розвиток яких багато в чому визначається інтенсивним поєднанням принципів узагальненої та програмної образності [6].

Варто зауважити, що в українському музичному мистецтві неабияку роль відіграла творчість композитора М. Скорика. Серед значного різноманіття творів у нього знайшлося місце і для збірки п'єс для дітей («3 дитячого альбому» (1965 р.)), яка стала важливим надбанням для фортепіанного педагогічного репертуару. В означеній збірці композитор уводить в український фольклор елементи джазового стилю. М. Скорик не використовує казкових героїв, різних сценок, забав та іграшок, він чинить зовсім по-іншому, що засвідчують навіть назви творів даного репертуару, яким характерне яскраве зображення фольклорних жанрів.
Збірка «3 дитячого альбому» відображає ідеї Б. Бартока у циклі «Мікрокосмос», які кардинально відрізняються від музики його попередників [9, с. 114]. Вона вміщує в собі п'ять мініатюр: «Простенька мелодія», «Народний танець», «Естрадна п’єса», «Лірник», «Жартівлива п’єса».

У 1981 р. для юних початківців композитор Л. Колодуб написав 27 п’єс, які назвав «Альбом для дітей». Він був прихильником класичної музики, тому образи для дитячих п'єс запозичував зі збірок П. Чайковського, В. Косенка та Р. Шумана. Митець творив у жанрі пісні та польки, при цьому робив свою музику особливою за допомогою постукувань по кришці фортепіано або застосування гармоній та ритмів джазу. Таким чином, його музика мала постійний рух.

В означений період до урізноманітнення дитячої гри приєднався В. Бібік, створивши збірку «Музика для дітей» (1983р.). Музика була написана схематично разом із сучасною технікою педалізації, різними авторськими позначеннями та вказівками. Праці «3 дитячого альбому», «Альбом для дітей» та «Музика для дітей» зароджують в українській фортепіанній музиці елементи джазу, постукування по фортепіано, авторські ремарки тощо. Для дітей усе це було незвичним, новим та дуже цікавим, тому вони із неабияким задоволенням виконували таку музику [6].

В Україні у XX - XXI столітті дитяча фортепіанна музика стає самостійною, розвиненою та досить різноманітною галуззю мистецтва. Зокрема, композитор О. Білаш створює фортепіанний цикл «Тетянчин альбом» (2000р.), що складається з 11 мініатюр, причому мелодизм композитора відчувається в кожному твоpi. Натомість у 2004 р. Г. Сасько пише фортепіанний цикл «Мозаїка», який вміщує 18 творів різних жанрів та стильових напрямів. Фактура циклу, що характеризувалася імітаційними звуками природи та етнічними назвами творів, була зображальною [10, с. 10].

Музика для дітей є дуже відповідальною, клопіткою і психологічно виваженою сферою мистецтва. Вона має виховувати не лише духовно, а й естетично, сприяти формуванню здатності дитини сприймати навколишній світ, знаходити різнобарв'я та чути красу звуків.

Для того, аби писати музику для дітей, композитору необхідно усвідомити, що вона дасть дитині і чи їй це дійсно потрібно. Адже він відповідає за створене, до того ж не всім вдається знайти правильний підхід у музичній мові [4]. Діти щиро реагують на музику, їхні емоції справжні, нефальшиві. Як стверджував Д. Кабалевський: «Діти здатні сприймати, запам'ятовувати та відтворювати досить складну музику, якщо ця музика яскрава, образна і природна у своєму розвиткові. Якщо ж немає в ній яскравості, образності й природності, навіть найпростішу музику діти ніколи не сприймуть і не запам'ятають, бо вона не зворушить їхніх сердець, не вплине на їхню свідомість» [3, с. 8]. Музика для дітей відображає духовний стан композитора, його ставлення до дітей, емоційний стан та почуття.

Висновки. Отже, зважаючи на означене вище, можемо стверджувати, що впродовж декількох століть у розвиткові та написанні дитячої фортепіанної музики відбулося чимало змін. Музична мова значно розширила межі усталених норм, як наслідок - вплив народної музики, багата уява, неординарне мислення та брак різножанрової музики відобразилися 
на оновленому стилі та видозміні інтонаційної й тематичної сфери образів. Засоби музичної виразності постійно урізноманітнюються та розвиваються, що робить звучання особливим і ні на що не схожим. Таким чином, українські композитори впевнено вносять елементи сучасної музики в дитячу фортепіанну літературу.

\section{СПИСОК ВИКОРИСТАНОЇ ЛІТЕРАТУРИ}

1. Барвінський В. Колядки і щедрівки на фортеп'ян 3 підложеним текстом / В. Барвінський. Львів : Видання Музичного товариства ім. М. Лисенка, 1935. -24 c

2. Булка Ю. Нестор Нижанківський: життя і творчість / Ю. Булка. - Львів ; Нью-Йорк : вид-во М. П. Коць, 1997. - 60 c

3. Кабалевський Д. Як розповідати дітям про музику / Д. Кабалевський. - К. : Музична Україна, 1982. $320 \mathrm{c}$.

4. Мозгальова Н. Г. Виховні можливості фортепіанної музики для дітей / Н. Г. Мозгальова. URL: https://library.udpu.edu.ua/library files/psuh pedagog probl silsk shkolu/9/visnuk_23.pdf (дата звернення: 02.09.2109).

УДК 781.43+786.2.002(045)

DOI: 10.37026/2520-6427-2019-100-4-173-177
5. Милич Б. Фортеп’янна література українських радянських композиторів для дітей та юнацтва / Б. Милич. - К. : Держ. вид. обр. мист. і муз. літ. УРСР, 1961. $-104 \mathrm{c}$.

6. Ніколаї Г. Ю. Українська фортепіанна музика як феномен культури 20 століття / Г. Ю. Ніколаї. URL: https://scholar.google.com.ua/citations?user=y5ATWyY AAAAJ\&hl=ru (дата звернення: 29.08.2019).

7. Олійник О. Українська фортепіанна музика для дітей / О. Олійник. - К. : Наук. думка, 1979. - 107 с.

8. Рудницька О. П. Музика і культура особистості: проблеми сучасної педагогічної освіти [Текст] : навчальний посібник / О. П. Рудницька ; АПН України, Інститут педагогіки. - К. : [б. в.], 1996. - 247 с.

9. Скорик М. Твори для фортепіано : навчально-методичний посібник / М. Скорик. - Львів : Сполом, 2008. - 220 с.

10. Тимощук О. Фортепіанні цикли для дітей у творчості українських композиторів: образно-художній аспект : автореф. дис. на здобуття наукового ступеня канд. мистецтвознавства : спец. 17.00.03 «Музичне мистецтво» / О. Тимощук. - Одеса, 2011. - 18 с.

Дата надходження до редакиії: 05.09.2019 p.

\section{Станіслав ДИМЧЕНКО,}

професор кафедри народних інструментів

Інституту мистеитв Рівненського державного

гуманітарного університету,

заслужений працівник культури Украӥни,

відмінник освіти Украӥни

Іван КАЛАШНІКОВ,

студент магістратури кафедри народних інструментів Інституту мистецтв Рівненського державного гуманітарного університету

\section{МУЗИЧНА ОРНАМЕНТИКА ТА ÏЇ РОЛЬ У ФОРМУВАННІ ВИКОНАВСЬКОЇ МАЙСТЕРНОСТІ СТУДЕНТІВ КЛАСУ БАЯНА}

У статті розглянуто специфічні особливості виконання музичної орнаментики на баяні, зокрема проаналізовано особливості виконавської орнаментики з урахуванням музики різних жанрів, епох, стилів, а також окреслено виконавську інтерпретацію мелізмів на баяні.

Ключові слова: орнаментачія, прикраса, мелізми, трель, форшлаг, мордент, групето.

B статье рассмотрень специфические особенности исполнения музыкальной орнаментики на баяне, в частности проанализированы особенности исполнительской орнаментики с учетом музыки разных жанров, эпох, стилей, а также описана исполнительская интерпретация мелизмов на баяне.
Ключевые слова: орнаментачия, украшения, мелизмы, трель, групетто, форшлаг, мордент.

The article discusses issues that continue to further explore various aspects of the development of bayan music, questions of a detailed study of artistic features and style professional works for folk instruments, which defined in modern musicology as the starting point in the process of professionalization and acculturation of this field of performing arts.

On the basis of the analysis of fundamental works of famous scientists - musicologists and music teachers, the question is raised about the urgency of the development of problems related to the correct implementation of textual means of expression, in particular, melismism, 